\title{
Faktor-Faktor yang Berhubungan dengan Kecemasan Ibu Hamil menjelang Persalinan
}

\author{
Anastasia C.Batu ${ }^{1}$, Susaldi ${ }^{2}$, Amelia Siswanto ${ }^{3}$, Feria K.Wulandari ${ }^{4}$, Intan Mistiana ${ }^{5}$, Liya \\ Juliska $\mathrm{SA}^{6}$, Resnawati ${ }^{7}$ \\ 1,3,4,5,6,7 Program Studi Sarjana Terapan Kebidanan STIKIM Jakarta \\ ${ }^{2}$ Departemen Keperawatan STIKes Indonesia Maju \\ Email: ${ }^{1}$ anastasiabatu@gmail.com, ${ }^{2}$ susaldi@ @stikim.ac.id
}

\section{Editor: WK}

Diterima: 13 September 2021

Direview: 26 Oktober 2021

Publish: 16 November 2021

Available Article: (doi)

\section{Hak Cipta:}

(C2021 Artikel ini memiliki akses terbuka dan dapat didistribusikan berdasarkan ketentuan Lisensi Atribusi Creative Commons, yang memungkinkan penggunaan, distribusi, dan reproduksi yang tidak dibatasi dalam media apa pun, asalkan nama penulis dan sumber asli disertakan. Karya ini dilisensikan di bawah Lisensi Creative Commons Attribution-Share Alike 4.0 Interna-sional.

\begin{abstract}
Abstrak
Latar Belakang: Kecemasan dan kekhawatiran adalah penyakit mental yang paling umum di Dunia. Kecemasan masih dianggap sebagai pengalaman alami bagi semua manusia dan telah dianggap sebagai bagian dari kehidupan sehari-hari. Namun, jika kecemasan berkepanjangan dan tidak dikelola dengan baik, dapat menyebabkan syok emosional dan efek buruk pada tubuh, yang dapat berubah menjadi penyakit kronis. Tujuan: Penelitian ini bertujuan untuk melihat faktor-faktor apa saja yang berhubungan dengan kecemasan ibu hamil menjelang persalinan di Indonesia.

Metode: Literatur review dilakukan dengan mengekstrak 6 Jurnal ilmiah tentang faktor-faktor yang berhubungan dengan kecemasan ibu hamil menjelang persalinan di Indonesia. Jurnal ini diambil dari website Google Scholar kemudian dipilih dengan menetapkan limit atau filter yaitu antara tahun 20152020, formal full text dengan kata kunci: kecemasan, ibu hamil, dan persalinan.

Hasil: Hasil analisis dari literatur riview menunjukkan bahwa faktor-faktor yang berhubungan dengan kecemasan ibu hamil menjelang persalinan di Indonesia dari 6 jurnal ilmiah yang dilakukan review oleh penelilti diperoleh hasil dari beberapa jurnal yang menyatakan bahwa terdapat hubungan antara pengetahuan, dukungan keluarga, dan paritas dengan kejadian kecemasan ibu hamil menjelang persalinan.

Kesimpulan: Adanya hubungan pengetahuan ibu hamil trisemester III, usia ibu, paritas ibu, dan dukungan keluarga terhadap tingkat kecemasan ibu hamil.
\end{abstract}

Kata Kunci: ibu hamil, kecemasan, persalinan. 


\section{Pendahuluan}

Kecemasan dan kekhawatiran adalah penyakit mental yang paling umum di Dunia. Kecemasan masih dianggap sebagai pengalaman alami bagi semua manusia dan telah dianggap sebagai bagian dari kehidupan sehari-hari. Namun, jika kecemasan berkepanjangan dan tidak dikelola dengan baik, dapat menyebabkan syok emosional dan efek buruk pada tubuh, yang dapat berubah menjadi penyakit kronis. ${ }^{1}$

Menurut Organisasi Kesehatan Dunia (2017), gangguan kecemasan merupakan masalah serius, mempengaruhi 14,9\% orang di seluruh dunia, atau sekitar 264 juta orang. Lebih dari 300 juta orang menderita depresi dan 260 juta menderita gangguan kecemasan. ${ }^{2}$ Data Survei Kesehatan Dasar (Riskesdas) Kementerian Kesehatan tahun 2018 menunjukkan bahwa prevalensi depresi dan gangguan jiwa terkait kecemasan di Indonesia adalah 6,1\% pada usia 15 tahun atau lebih. Artinya, lebih dari 1 juta orang di Indonesia menderita gangguan jiwa. ${ }^{3}$

Ada dua faktor yang mempengaruhi kecemasan, antara lain internal (jenis kelamin, usia, pendidikan, pengalaman kehamilan) dan ekstrnal (kondisi medis/diagnosis, akses terus menerus terhadap informasi, komunikasi terapeutik, lingkungan, fasilitas medis). Ibu hamil yang sedang memeriksakan kandungannya atau bersiap untuk melahirkan di rumah sakit mengalami ketakutan dan kecemasan. Ini adalah respons khas terhadap kunjungan rumah sakit, tetapi perasaan ini memanifestasikan dirinya dengan cara yang berbeda. ${ }^{4}$

Menurut Mansjoer, kehamilan adalah suatu fenomena fisiologis yang dimulai dengan pembuahan dan diakhiri dengan proses persalinan. ${ }^{5}$ Pada saat ibu hamil, akan merasakan kegelisahan mengenai kelahiran bayi dan permulaan dari fase baru dalam hidup calon ibu. ${ }^{6}$ Rasa cemas yang dialami oleh ibu hamil itu disebabkan karena meningkatnya hormon progesteron. Selain membuat ibu hamil merasa cemas, peningkatan hormon itu juga menyebabkan gangguan perasaan dan membuat ibu hamil cepat Lelah. ${ }^{7}$ Kecemasan dapat diatasi dengan metode farmakologi dan non farmakologi. Manajemen kecemasan tanpa obat dapat dicapai melalui perawatan seperti relaksasi, distraksi, hipnosis lima jari, dan aktivitas mental. ${ }^{8}$ Tidak hanya itu, metode lain yang dapat digunakan dengan pendekatan non-obat antara lain relaksasi, pijat, aromaterapi, hipnosis, akupunktur, dan yoga. ${ }^{9}$ Menurut Perry dkk. (2010) Jatonika, dkk (2016) Terapi alternatif penting untuk kehamilan adalah pijat dan terapi energi seperti pijat, akupresur, sentuhan terapeutik, sentuhan penyembuhan, dan penyembuhan mental dan fisik seperti visualisasi, meditasi/yoga, doa, refleksi. Biofeedback. ${ }^{9}$

\section{Metode}

Studi penelitian ini adalah literature review, dimana jurnal-jurnal yang dipilih adalah semua penelitian yang mencakup dengan faktor-faktor yang berhubungan dengan kecemasan ibu hamil menjelang persalinan. Jurnal atau penelitian ini dipilih dengan menetapkan limit atau filter yaitu antara tahun 2015-2020, format full text. Dengan kata kunci: ibu hamil, kecemasan, persalinan. Jurnal didapatkan dari sumber jurnal-jurnal ilmiah yaitu website google scholar.

Kriteria inklusinya adalah ibu hamil trimester III, yang di teliti adalah faktor yang berhubungan dengan kecemasan, penelitian dilakukan di Indonesia. Kriteria eksklusinya adalah faktor-faktor yang berhubungan dengan kecemasan ibu hamil. Literatur atau jurnal adalah jurnal-jurnal yang didapat dari website google schooler, kemudian diekstrak/disaring sesuai topik dan kriteria inklusi. Jurnal yang didapat terdiri dari Jurnal Bidan, jurnal Kesehatan Masyarakat Aceh (MaKMA), Jurnal JKFT: Universias Muhammadiyah Tangerang, Jurnal Kesehatan Metro Sai Wawai, Jurnal Imu Kesehatan Aisyah, Jurnal Keperawatan. Berikut 
jurnal-jurnal yang diperoleh sesuai topik penelitian, yaitu kecemasan pada ibu hamil menjelang persalinan.

Hasil

Tabel 1. Artikel Review

\begin{tabular}{|c|c|c|c|c|c|}
\hline No & Penulis & $\begin{array}{l}\text { Judul } \\
\text { Penelitian }\end{array}$ & Tujuan & $\begin{array}{l}\text { Metode } \\
\text { Penelitian }\end{array}$ & Hasil Penelitian \\
\hline 1. & $\begin{array}{l}\text { Hanifah \& } \\
\text { Utami (2019) }\end{array}$ & $\begin{array}{l}\text { Faktor-faktor } \\
\text { yang } \\
\text { mempengaruhi } \\
\text { kecemasan } \\
\text { antenatal }\end{array}$ & $\begin{array}{l}\text { Mengidentifikasi } \\
\text { kecemasan } \\
\text { antenatal dan } \\
\text { analisis faktor- } \\
\text { faktor yang } \\
\text { berhubungan } \\
\text { dengan kejadian } \\
\text { kecemasan } \\
\text { antenatal }\end{array}$ & $\begin{array}{l}\text { cross } \\
\text { sectional. }\end{array}$ & $\begin{array}{l}\text { Faktor yang berhubungan dengan kecemasan } \\
\text { antenatal diantaranya paritas }(\mathrm{p}=0,003) \text {, status } \\
\text { obstetri }(\mathrm{p}=0,000) \text {, usia kehamilan }(\mathrm{p}=0,001) \text {, } \\
\text { dukungan keluarga }(\mathrm{p}=0,000) \text { dan perilaku } \\
\text { kesehatan }(\mathrm{p}=0,000) .{ }^{4}\end{array}$ \\
\hline 2. & $\begin{array}{l}\text { Ismail, dkk } \\
\text { (2019) }\end{array}$ & $\begin{array}{l}\text { Berbagai Faktor } \\
\text { yang } \\
\text { Mempengaruhi } \\
\text { Tingkat } \\
\text { Kecemasan Ibu } \\
\text { Hamil Trimester } \\
\text { III }\end{array}$ & $\begin{array}{l}\text { Mengetahui } \\
\text { faktor-faktor yang } \\
\text { mempengaruhi } \\
\text { tingkat kecemasan } \\
\text { ibu hamil } \\
\text { trimester III di } \\
\text { Wilyah Kerja } \\
\text { Puskesmas } \\
\text { Samalanga } \\
\text { Kabupaten Bireun } \\
\text { Tahun } 2018\end{array}$ & $\begin{array}{l}\text { cross } \\
\text { sectional }\end{array}$ & $\begin{array}{l}\text { Dari hasil uji statistik chi-square dapat } \\
\text { disimpulkan bahwa ada pengaruh pengetahuan } \\
(P \text {-value } 0,025<0,05) \text {, psikologis }(P \text {-value } \\
0,014<0,05) \text {, dukungan keluarga }(P \text {-value } 0,048 \\
<0,05) \text {, dan tidak ada pengaruh pendapatan }(P \text { - } \\
\text { value } 0,055>0,05) \text { terhadap tingkat kecemasan } \\
\text { ibu hamil trimester III di Wilayah Kerja } \\
\text { Puskesmas Samalanga Kabupaten Bireuen Tahun } \\
\text { 2019. }{ }^{10}\end{array}$ \\
\hline 3. & $\begin{array}{l}\text { Zuhrotunida \& } \\
\text { Yudiharto } \\
\text { (2017) }\end{array}$ & $\begin{array}{l}\text { Hubungan } \\
\text { Dukungan } \\
\text { Keluarga } \\
\text { dengan } \\
\text { Kecemasan Ibu } \\
\text { Hamil } \\
\text { Menghadapi } \\
\text { Proses } \\
\text { Persalinan di } \\
\text { Puskesmas } \\
\text { Kecamatan } \\
\text { Mauk } \\
\text { Kabupaten } \\
\text { Tangerang }\end{array}$ & $\begin{array}{l}\text { Mengetahui } \\
\text { apakah ada } \\
\text { hubungan antara } \\
\text { karakteristik ibu } \\
\text { hamil dan } \\
\text { dukungan } \\
\text { keluarga dengan } \\
\text { kecemasan ibu } \\
\text { hamil menghadapi } \\
\text { proses persalinan } \\
\text { di Puskesmas } \\
\text { Mauk. }\end{array}$ & $\begin{array}{l}\text { cross } \\
\text { sectional }\end{array}$ & $\begin{array}{l}\text { Hasil penelitian menunjukkan tidak ada } \\
\text { hubungan antara karakterisitik ibu hamil dengan } \\
\text { kecemasan ibu hamil dalam menghadapi proses } \\
\text { persalinan dengan p-value >0,05, tetapi ada } \\
\text { hubungan antara dukungan keluarga dengan } \\
\text { kecemasan ibu hamil dalam menghadapi proses } \\
\text { persalinan di Puskesmas Mauk dengan p-value } \\
0,000<0,05.11\end{array}$ \\
\hline 4. & $\begin{array}{l}\text { Martini \& } \\
\text { Oktaviani } \\
(2016)\end{array}$ & $\begin{array}{l}\text { Hubungan } \\
\text { Karakteristik } \\
\text { Ibu Hamil TM } \\
\text { Tiga dengan } \\
\text { Kecemasan Ibu } \\
\text { Menghadapi } \\
\text { Persalinan di } \\
\text { Metro }\end{array}$ & $\begin{array}{l}\text { Mengetahui } \\
\text { hubungan antara } \\
\text { karakteristik ibu } \\
\text { hamil trimester III } \\
\text { (umur, graviditas, } \\
\text { tingkat } \\
\text { pendidikan, } \\
\text { pekerjaan, dan } \\
\text { status kesehatan) } \\
\text { dengan } \\
\text { kecemasan dalam } \\
\text { menghadapi } \\
\text { persalinan. }\end{array}$ & $\begin{array}{l}\text { cross } \\
\text { sectional. }\end{array}$ & $\begin{array}{l}\text { Hasil penelitian menunjukkan dari lima variabel } \\
\text { yang diteliti, dua variabel ternyata tidak dapat } \\
\text { membuktikan adanya hubungan, yaitu umur } \\
(\mathrm{p}=0.568) \text {, pekerjaan }(\mathrm{p}=0.592) \text {, sedangkan } \\
\text { variabel yang lain yaitu graviditas }(\mathrm{p}=0.022) \text { dan } \\
\text { tingkat pendidikan ( } \mathrm{p}=0.047) \text { dan status } \\
\text { kesehatan ( } \mathrm{p}=0.010) \text { secara statistik dapat } \\
\text { membuktikan adanya hubungan yang signifikan } \\
\text { dengan kecemasan dalam menghadapi } \\
\text { persalinan. }\end{array}$ \\
\hline
\end{tabular}




\section{OAJJHS}

Vol. 01, No. 02, November 2021

P-ISSN 2798-2033, E-ISSN 2798-1959

DOI 10.53801/oajjhs.v1i3.22

\begin{tabular}{|c|c|c|c|c|c|}
\hline 5. & Heriani (2016) & $\begin{array}{l}\text { Kecemasan } \\
\text { dalam } \\
\text { Menjelang } \\
\text { Persalinan } \\
\text { Ditinjau dari } \\
\text { Paritas, Usia } \\
\text { dan Tingkat } \\
\text { Pendidikan }\end{array}$ & $\begin{array}{l}\text { Mengetahui } \\
\text { hubungan paritas, } \\
\text { usia dan tingkat } \\
\text { pendidikan } \\
\text { dengan } \\
\text { kecemasan dalam } \\
\text { menjelang } \\
\text { persalinan. }\end{array}$ & $\begin{array}{l}\text { cross } \\
\text { sectional }\end{array}$ & $\begin{array}{l}\text { Analisis statistik menggunakan chi square pada } \\
\text { variabel paritas, usia dan tingkat pendidikan } \\
\text { responden terhadap kecemasan dalam menjelang } \\
\text { persalinan masing-masing di peroleh nilai } p \text { - } \\
\text { value }=0,008 \text {, } p \text {-value }=0,002 \text {, } p \text {-value }=0,011 \text {. } \\
\text { Terdapat hubungan antara paritas, usia dan } \\
\text { tingkat pendidikan ibu hamil trimester III dengan } \\
\text { tingkat kecemasan dalam menghadapi masa } \\
\text { menjelang persalinan di UPTD Puskesmas } \\
\text { Tanjung Agung Tahun 2016. }{ }^{13}\end{array}$ \\
\hline 6. & $\begin{array}{l}\text { Arifin, dkk } \\
\text { (2015) }\end{array}$ & $\begin{array}{l}\text { Hubungan } \\
\text { Dukungan } \\
\text { Keluarga } \\
\text { dengan } \\
\text { Kecemasan Ibu } \\
\text { Hamil } \\
\text { Menghadapi } \\
\text { Proses } \\
\text { Persalinan di } \\
\text { Puskesmas } \\
\text { Budilatama } \\
\text { Kecamatan } \\
\text { Gadung } \\
\text { Kabupaten Buol } \\
\text { Propinsi } \\
\text { Sulawesi } \\
\text { Tengah }\end{array}$ & $\begin{array}{l}\text { Mengetahui } \\
\text { hubungan } \\
\text { kecemasan ibu } \\
\text { hamil dan } \\
\text { dukungan } \\
\text { keluarga terhadap } \\
\text { persalinan di } \\
\text { puskesmas } \\
\text { budilatama } \\
\text { kabupaten buol }\end{array}$ & $\begin{array}{l}\text { Cross } \\
\text { Sectional }\end{array}$ & $\begin{array}{l}\text { Ada hubungan yang signifikan antara dukungan } \\
\text { keluarga dengan kecemasan ibu hamil dengan } \\
\text { nilai } \mathrm{P}=0,009(\mathrm{P}<0,05) \text { dengan menggunakan } \\
\text { chi-square. }{ }^{14}\end{array}$ \\
\hline
\end{tabular}

Banyak faktor penyebab kecemasan pada ibu hamil menjelang persalinan di Indonesia dari 6 jurnal ilmiah yang dilakukan review oleh penelilti diperoleh hasil dari beberapa jurnal yang menyatakan bahwa terdapat hubungan antara pengetahuan, dukungan keluarga, dan paritas dengan kejadian kecemasan ibu hamil menjelang persalinan. Dan terdapat satu jurnal dari literature riview dengan hasil yang berbeda yang menyatakan tidak ada Hubungan bermakna antara usia dengan kecemasan ibu hamil menjelang persalinan.

\section{Pembahasan}

\section{Hubungan Pengetahuan dengan Kecemasan Ibu Hamil}

Berdasarkan dari beberapa penelitian yang didapatkan yaitu Pengetahuan merupakan faktor predisposisi yang kuat terhadap stabilitas kondisi fisilogis. Pendidikan kesehatan pada pasien telah menunjukkan potensinya untuk meningkatkan kepuasan pasien, memperbaiki kualitas kehidupan, memastikan kelangsungan perawatan, secara efektif mengurangi insiden komplikasi penyakit, memasyarakatkan masalah kepatuhan terhadap rencana. pemberian perawatan kesehatan dan menurunkan ansietas serta memaksimalkan kemandirian dalam melakukan aktifitas kehidupan sehari- hari. Pengetahuan ibu hamil yang kurang tentang proses persalinan merupakan salah satu penyebab kecemasan yang terjadi pada ibu hamil, sehingga pengetahuan ibu hamil tentang proses persalinan sangat penting untuk dikaji dalam mempersiapkan ibu hamil menghadapi persalinanannya.

Hasil penelitian ini sejalan dengan yang dilakukan Fauziah (2016), Pengetahuan Tentang Kehamilan Ibu Primigravida Trimester III dengan nilai $P$-Value $=0,055<0,05$, maka Ha 
ditolak. ${ }^{15}$ Penelitian yang sama juga dilakukan oleh oleh Harmia (2015), menunjukkan bahwa dari 127 responden terdapat nilai $P$-Value $=0,004<0,05$. Hal ini disebabkan adanya hubungan pengetahuan ibu hamil trisemester III tentang proses persalian dengan tingkat kecemasan ibu menghadapi persalinan di Desa Tarai Bangun Wilayah Kerja Puskesmas Tambang Tahun 2015 .

Pengetahuan ibu hamil rendah mengakibatkan seseorang mudah mengalami stress. Ketidaktahuan terhadap suatu hal dianggap sebagai tekanan yang dapat mengakibatkan krisis dan dapat menimbulkan kecemasan. Kecemasan dapat terjadi pada individu dengan tingkat pengetahuan yang rendah, disebabkan karena kurangnya informasi yang diperoleh. ${ }^{6}$

Berdasarkan pada hasil penelitian menurut Sri Handayani, analisa univariat yang dilakukan pada 34 ibu dengan persentase jumlahnya adalah sebagian besar berpengetahuan baik yaitu $16 \mathrm{ibu}(47,1 \%)$, berpengetahuan cukup sebanyak $10 \mathrm{ibu}(29,4 \%)$, sedangkan yang berpengetahuan kurang sebanyak 8 ibu $(23,5 \%) .{ }^{16}$ Pengetahuan adalah hasil dari tahu dan ini terjadi setelah orang melakukan penginderaan terhadap suatu objek tertentu. Penginderaan terjadi melalui panca indera manusia, yakni indera penglihatan, pendengaran, penciuman, rasa, dan raba. Sebagian besar pengetahuan manusia diperoleh melalui mata dan telinga. Pengetahuan atau kognitif merupakan domain yang sangat penting untuk terbentuknya tindakan seseorang overt behavior. Pengetahuan dipengaruhi oleh beberapa faktor yaitu umur, tingkat pendidikan, pekerjaan, dan informasi mengalami kecemasan. ${ }^{17}$

\section{Hubungan usia dengan kecemasan ibu hamil}

Berdasarkan dari beberapa penelitian yang didapat ditemukan bahwa kecemasan antenatal dikategorikan menjadi ketakutan akan proses persalinan, kekhawatiran cacat janin dan kekhawatiran perubahan fisik. Jika dilihat dari kisaran umur sebagian besar responden pada kelompok usia 20-35 tahun mengalami tingkat kecemasan ringan, karena pada kelompok usia tersebut merupakan umur yang ideal/sesuai bagi para ibu dalam melakukan persalinan. ${ }^{12}$

Pada penelitian (Hanifah \& Utami, 2019) Terdapat 12,5\% ibu hamil berada pada kelompok beresiko yaitu usia kurang dari 20 tahun dan usia lebih dari 35 tahun. Kelompok usia beresiko merupakan kelompok usia yang secara fisiologi memiliki resiko terjadinya penyulit selama kehamilan dan persalinan. ${ }^{4}$ Menurut penelitian (Heriani, 2016) terdapat hubungan yang bermakna antara usia ibu dengan tingkat kecemasan dalam menghadapi masa menjelang persalinan. Hasil analisa hubungan usia ibu yang cemas menghadapi masa menjelang persalinan didapat proporsi responden dengan ibu hamil yang beresiko sebesar $81 \%$, lebih besar dari proporsi responden dengan usia tidak beresiko yang mengalami kecemasan sebesar $29,2 \% .^{13}$

Asumsi peneliti selain usia kurang dari 20 tahun berada pada kelompok ibu hamil beresiko, factor kehamilan perdana dan belum memiliki pengalaman dalam kehamilan dan melahirkan membuat ibu hamil mengalami kecemasan yang lebih tinggi dibandingkan ibu hamil usia 20-35 tahun.

\section{Hubungan Paritas dengan Kecemasan Ibu Hamil}

Berdasarkan review dari beberapa penelitian yang meneliti hubungan paritas terhadap kecemasan antenatal. Pada penelitian (Hanifah \& Utami, 2019) ditemukan terdapat hubungan paritas terhadap kecemasan antenatal (nilai P 0,003, OR 3,27 dan CI 1,48-7,28). Hal ini memperkuat penelitian sebelumnya, yaitu adanya hubungan yang signifikan anatar paritas 
dengan kecemasan antenatal. ${ }^{4}$ Wanita primipara cenderung lebih rentan mengalami kecemasan antenatal dikarenakan belum adanya pengalaman dalam menjalani proses kehamilan dan persalinan. ${ }^{18}$ Meskipun terdapat penelitian lain yang menyebutkan multipara lebih rentan mengalami kecemasan antenatal dibandingkan ibu primipara, yang dikarenakan adanya tuntutan dari keluarga terhadap kehamilan saat ini. ${ }^{18}$

Berdasarkan hasil analisis ditemukan terdapat hubungan signifikan antara riwayat penyulit pada kehamilan sebelumnya dengan kecemasan antenatal (nilai P 0,00, OR 0,029 dan CI 0,009-0,088). Hasil penelitian ini memperkuat penelitian di Brazil yang menunjukkan hasil yang sama bahwa riwayat penyulit pada kehamilan sebelumnya berhubungan dengan kecemasan antenatal. ${ }^{19}$

Pada penelitian (Heriani, 2016) menunjukkan hasil analisa hubungan Paritas Ibu yang cemas dalam menghadapi menjelang persalinan didapat proporsi responden primigravida sebesar $72,7 \%$ (8 responden), lebih besar dari proporsi ibu hamil dengan multigravidayang mengalami kecemasan sebesar 47,1\% (16 responden). Hasil uji statistik Chi-Square menunjukkan bahwa ada hubungan yang bermakna antara paritas ibu dengan tingkat kecemasan dalam menghadapi masa menjelang persalinan dengan $p$ value $0,008 .{ }^{13}$

\section{Hubungan Dukungan Keluarga dengan Kecemasan pada Ibu Hamil}

Hasil penelitian ini yang didapatkan dari 32 responden berdasarkan dukungan keluarga terhadap kecemasan ibu hamil menghadapi proses persalinan dengan dukungan baik sebanyak 17 responden $(53,1 \%)$ dan 15 responden mengatakan dukungan tidak baik $(46,9 \%)$. Dengan demikian dukungan keluarga sangat diharapkan oleh seorang ibu hamil dalam menghadapi proses persalinan, dengan dukungan keluarga yang baik akan mengurangi stressor pada ibu sehingga proses persalinan lebih lancar dan cepat tanpa menimbulkan komplikasi. Berdasarkan Sosa Musbikin 2005, menyatakan bahwa para ibu yang didampingi oleh seorang sahabat atau keluarga dekat (khususnya suami) selama proses persalinan berlangsung, memiliki resiko lebih kecil mengalami komplikasi yang memerlukan tindakan medis dari pada mereka yang tanpa pendampingan. ${ }^{20}$

Dukungan keluarga adalah sikap, tindakan dan penerimaan keluarga terhadap anggota keluarga yang lainnya. Kecemasan dianggap sebagai salah satu faktor penghambat kinerja fungsi-fungsi kognitif seseorang, seperti berkonsentrasi, mengingat, dan pemecahan masalah. Faktor yang mempengaruhi kecemasan yaitu potensi stressor, malnutrisi, keadaan fisik, selisih usia, jenis kelamin, pengetahuan dan sosial ekonomi. ${ }^{20}$

Hasil data penelitian yang dilakukan oleh Sulistyorini 2007 menunjukan bahwa dukungan yaitu cukup 8 responden $(29,6 \%)$, dan dukungan keluarga baik yaitu 19 responden $(70,4 \%)$. Hasil tingkat kecemasan pada ibu hamil menunjukan bahwa ibu hamil yang memiliki kecemasan ringan yaitu sebanyak $17 \mathrm{ibu}$ hamil $(63,0 \%)$, dan yang mengalami kecemasan sedang sebanyak 6 ibu hamil $(22,2 \%)$ Hasil penelitian menunjukan nilai $p$-value $=0,001<0,005$ berarti ada hubungan antara dukungan keluarga dengan tingkat kecemasan ibu hamil. ${ }^{21}$ Menurut hasi penelitian yang dilakukan oleh Sulistyorini (2007), di Desa Jepat Lor Kecamatan Tayu Kabupaten Pati menunjukan bahwa $(52,5 \%)$ ibu hamil menghadapi kelahiran anak pertama berada pada kategori kecemasan renda, (60\%) subjek menilai bahwa dukungan yang diperoleh dari keluarganya sangat tinggi. Wanita hamil dengan dukungan keluarganya yang tinggi tidak akan mudah menilai situasi dengan kecemasan karena wanita hamil dengan kondisi demikian tahu bahwa akan ada keluarganya yang membantu. Wanita hamil dengan dukungan keluarga yang tinggi akan mengubah respon terhadap sumber kecemasan dan pergi kepada 
keluarganya untuk mencurahkan isi hatinya. ${ }^{21}$ Sulistyorini (2007) dalam penelitiannya menyebutkan bahwa kecemasan menghadapi kelahiran bayi juga dipengaruhi oleh tingkat pengetahuan tentang kehamilan. Hal ini dikarenakan banyak dari para keluarga dan suami yang tidak mampu melihat kondisi isterinya saat melahirkan sehingga mengakibatkan dukungan untuk ibu dalam proses persalinan agak berkurang. Kebanyakan suami atau keluarga hanya menunggu persalinan diruang tunggu yang telah disedikan oleh bidan tanpa ada yang langsung ikut dalam proses persalinan. Kurangnya dukungan moral dari keluarga dan suami menyebapkan banyak ibu-ibu yang bersalin merasa khawatir dan takut menghadapi persalinan sehingga menyebapkan perasaan cemas saat berlangsung persalinan semakin bertambah. Hasil wawancara juga didapatkan 1 orang ibu yang mengatakan bahwaia selalu ditungui keluarganya saat melakukan pemeriksaan kehamilannya. Dukungan penuh yang diberikan keluarganya saat persalinan tersebut menjadikan ibu menjadi lebih tenang sehingga hal tersebut mengurangi kecemasan ibu saat menghadapi persalinan. ${ }^{21}$

\section{Kesimpulan}

Dari hasil penelitian dan pembahasan yang telah dilakukan maka penulis mengambil kesimpulan sebagai berikut: Adanya hubungan pengetahuan ibu hamil trisemester III tentang proses persalian dengan tingkat kecemasan ibu menghadapi persalinan; Adanya hubungan yang bermakna antara usia ibu dengan tingkat kecemasan dalam menghadapi masa menjelang persalinan; Adanya hubungan yang bermakna antara paritas ibu dengan tingkat kecemasan dalam menghadapi masa menjelang persalinan dengan $p$-value 0,008; Adanya hubungan antara dukungan keluarga dengan tingkat kecemasan ibu hamil.

\section{Konflik Kepentingan}

Dalam penelitian ini peneliti menyatakan tidak ada konflik kepentingan baik secara individu maupun secara organisasi.

\section{Ucapan Terima Kasih}

Penulis mengucapkan terima kasih yang sebesar-besarnya kepada dosen mata kuliah big data bapak Susaldi, S.ST., M.Biomed dan seluruh pihak yang telah membantu dalam pengerjaan naskah artikel ini. Semoga dapat memberi manfaat bagi banyak orang.

\section{Pendanaan}

Sumber pendanaan diperoleh dari penulis.

\section{References}

1. Maulana I, Suryani S, Sriati A, Sutini T, Widianti E, Rafiah I, et al. Penyuluhan Kesehatan Jiwa untuk Meningkatkan Pengetahuan Masyarakat tentang Masalah Kesehatan Jiwa di Lingkungan Sekitarnya. Media Karya Kesehat. 2019;2(2).

2. Health AI of. Mental Health Services: In Brief 2012. AIHW; 2012.

3. Riskesdas K. Hasil Utama Riset Kesehata Dasar (RISKESDAS). J Phys A Math Theor. 2018;44(8):1200.

4. Hanifah D, Utami S. Faktor-Faktor yang Mempengaruhi Kecemasan Antenatal. J Kebidanan Malahayati. 2019;5(1):16-23.

5. Maryati S, Jati SP, Wulan LRK. ANALISIS PROGRAM AUDIT MATERNAL-PERINATAL (AMP) DI KABUPATEN CIANJUR TAHUN 2012. J Kesehat Budi Luhur J Ilmu-Ilmu Kesehat Masyarakat, Keperawatan, dan Kebidanan. 2019;12(2):172-81.

6. MANGGARSARI MDWI. Stres pada Saat Akan Melahirkan antara Ibu yang Melakukan Hypnobirthing 
dan yang Tidak Melakukan Hypnobirthing. PRODI PSIKOLOGI UNIKA SOEGIJAPRANATA; 2010.

7. Martalisa W, Budisetyani W. Hubungan intensitas keikutsertaan hypnobirthing dengan tingkat kecemasan ibu hamil di gianyar. J Psikol Udayana. 2013;1(1):116-28.

8. Marbun A, Pardede JA, Perkasa SI. Efektivitas Terapi Hipnotis Lima Jari terhadap Kecemasan Ibu Pre Partum di Klinik Chelsea Husada Tanjung Beringin Kabupaten Serdang Bedagai. J Keperawatan Prior. 2019;2(2):92-9.

9. Rika VNA, Aryanti L. Pengaruh Massage Effleurage Terhadap Nyeri Persalinan Pada Ibu Inpartu Kala I Fase Aktif Di Rumah Sakit Ibu Dan Anak Sinta Bandar Lampung. Holistik J Kesehat. 2014;8(4).

10. Ismail, Usman S, Maulida M. Berbagai Faktor yang Mempengaruhi Tingkat kecemasan Ibu Hamil Trimester III. Maj Kesehat Masy Aced e-ISSN 2621-8178. 2019;2(3):120-30.

11. Zuhrotunida Z, Yudiharto A. Hubungan Dukungan Keluarga Dengan Kecemasan Ibu Hamil Menghadapi Proses Persalinan Di Puskesmas Kecamatan Mauk Kabupaten Tangerang. J JKFT. 2017;2(2):60-70.

12. Martini M, Oktaviani I. HUBUNGAN KARAKTERISTIK IBU HAMIL TM TIGA DENGAN KECEMASAN IBU MENGHADAPI PERSALINAN DI METRO. J Kesehat Metro Sai Wawai. 2016;9(1):1-6.

13. Heriani H. Kecemasan dalam Menjelang Persalinan Ditinjau Dari Paritas, Usia dan Tingkat Pendidikan. J Aisyah J Ilmu Kesehat. 2016;1(2):Hal-01.

14. Arifin A, Kundre R, Rompas S. Hubungan Dukungan Keluarga Dengan Kecemasan Ibu Hamil Menghadapi Proses Persalinan Di Puskesmas Budilatama Kecamatan Gadung Kabupaten Buol Propinsi Sulawesi Tengah. J keperawatan. 2015;3(2).

15. Fauziah NA, Komalasari K, Primadevi I, Farokah A. Senam Yoga Terhadap Tingkat Kecemasan Ibu Hamil Trimester III. J Aisyah J Ilmu Kesehat. 2021;6:171-4.

16. Handayani S. HUBUNGAN PENGETAHUAN, SIKAP DAN PERILAKU IBU HAMIL TENTANG PEMERIKSAAN KEHAMILAN DENGAN FREKUENSI KUNJUNGAN PEMERIKSAAN KEHAMILAN. J KEPERAWATAN GSH. 2020;7(2):10-7.

17. Fauzi RN, Syaifudin A, Kustriyanti D. Hubungan Pengetahuan Perawat Dengan Pencegahan Keselamatan Pasien Risiko Jatuh Pada Pasien Pasca Operasi Di Rumah Sakit Kota Semarang. J Smart Keperawatan. 2016;3(1).

18. Fathony Z, Amalia R, Lestari PP. Effects Of The Covid-19 Pandemic On The Trends Of Pregnant Mother Anxiety Disorders In South Kalimantan In 2021. Heal J. 2021;5(1):13-6.

19. Lima M, da Silva Junior CA, Rausch L, Gibbs HK, Johann JA. Demystifying sustainable soy in Brazil. Land use policy. 2019;82:349-52.

20. Sari FS. Dukungan Yang Terima Pada Primipara Saat Diputuskan Sectio Caesarea Darurat. Menara Ilmu. 2018;12(1).

21. Rahmi L. Hubungan usia, tingkat pendidikan, dukungan suami, dan dukungan keluarga dengan tingkat kecemasan menjelang persalinan pada ibu primigravida trimester III di poliklinik kebidanan RSUP dr. M. Djamil padang tahun 2009. Penelitian, Fak Keperawatan. 2010; 